\title{
Hematoma after augmentation mammaplasty in a patient with von Willebrand's disease
}

\author{
Hematoma após mamaplastia de aumento em paciente portadora de doença de \\ von Willebrand
}

\author{
Marco Willians Baena \\ DESTRO $^{1}$ \\ Áurea Regina Rodrigues ${ }^{2}$ \\ João Lúcio Rodrigues de \\ Castro $^{3}$ \\ Cristina Destro ${ }^{4}$ \\ Luiz Gustavo Capochin \\ RomaGNOLO 5 \\ Study conducted at the Regional \\ Hospital of Taubaté, Taubaté, SP, \\ Brazil. \\ Submitted to SGP (Sistema de \\ Gestão de Publicações/Manager \\ Publications System) of RBCP \\ (Revista Brasileira de Cirurgia \\ Plástica/Brazilian Journal of \\ Plastic Surgery). \\ Received: October 29, 2009 \\ Accepted: March 1, 2010
}

\begin{abstract}
We present the case of a patient submitted to augmentation mammaplasty who developed 2 hematoma episodes as a result of von Willebrand's disease, which was not previously diagnosed. As a routine part of preoperative evaluation, the patient should always be tested for von Willebrand's disease. This disease affects $1-3 \%$ of the population and occurs twice as often as hemophilia. In our case, the patient recovered quite satisfactorily. Preventive and therapeutic approaches are discussed in this paper.
\end{abstract}

Keywords: von Willebrand diseases. Hematoma. Mammaplasty. Blood coagulation disorders. Coagulation protein disorders.

\section{RESUMO}

Os autores relatam o caso de uma paciente submetida a mamaplastia de aumento, não diagnosticada previamente como portadora de doença de von Willebrand, que teve dois episódios de hematoma no pós-operatório. Entre os distúrbios de coagulação, a doença de von Willebrand deve ser considerada na avaliação pré-operatória, pois afeta cerca de $1 \%$ a $3 \%$ da população, não é diagnosticada na maioria das pessoas, além de ser duas vezes mais frequente que a hemofilia. A paciente evoluiu bem no pós-operatório e medidas preventivas e terapêuticas são discutidas neste artigo.

Descritores: Doenças de von Willebrand. Hematoma. Mamoplastia. Transtornos da coagulação sanguínea. Transtornos de proteínas de coagulação.

\section{INTRODUCTION}

Von Willebrand's disease is hereditary and autosomaldominant. It is caused by a weakness or a dysfunction of a glycoprotein, "von Willebrand factor" (vWF), which is responsible for 1 step in platelet aggregation. The disease is caused by a mutation in chromosome 12 and is characterized by a qualitative or quantitative deficiency of $\mathrm{vWF}^{1,2}$. In rare cases, the disease is caused by a deficiency of factor VIII.

The disease, first described in 1926 by Finnish physician, von Willebrand ${ }^{3}$, affects about $1-3 \%$ of the world population. It is more frequently reported in women, most likely because of increased chances of diagnosis after hemorrhagic disorders during menstruation.

\section{Classifications}

Von Willebrand's disease is classified as follows:

- Type 1 - the most common type representing $60-80 \%$ of all cases. It is a quantitative defect in which the vWF deficiency stays within $20-50 \%$ of the normal value. Type 1 causes mild to moderate bleeding.

- Type 2 - a qualitative defect that represents $20-30 \%$ of all cases. Type 2 can be further divided into 4 subtypes:

- 2A: the most common subtype; the vWF has difficulty binding to platelets and the number of large multimers is reduced;

1. MD, PhD in Surgery from the Universidade Minas Gerais (UFMG); Full Professor in Plastic Surgery at the Universidade de Taubaté, Taubaté, SP, Brazil.

2. Hematologist of the Hemotherapy Service of the Hospital Regional de Taubaté, Taubaté, SP, Brazil.

3. Anesthesiologist, Coordinator of the Anesthesiology Service of the Hospital Regional de Taubaté, Taubaté, SP, Brazil.

4. Resident Physician of Plastic Surgery at the Plastic Surgery Institute of Santa Cruz, Taubaté, SP, Brazil.

5. Resident Physician of Surgery at the Hospital Regional de Taubaté, SP, Brazil. 
- 2B: the vWF has a high affinity to platelets and binds easily; therefore, the free circulation of VWF is diminished;

- 2M: there is no absence of large multimers, but it does not have the same capacity to bind to platelets;

- $2 \mathrm{~N}$ : the vWF loses the ability to bind with factor VIII.

- Type 3 - the most severe type; characterized by a total deficiency of the vWF. The patient may present severe bleeding.

- Acquired von Willebrand's Disease - is related to other diseases such as lymphoid diseases, multiple myeloma, macroglobulinemia, myeloproliferative disorders, some tumors, and autoimmune diseases. In general, it may or may not be caused by anti-vWF.

\section{Diagnosis}

The activated partial thromboplastin time (APTT) may be longer, as well as the duration of bleeding. The simple determination of the factor VIII levels does not diagnose von Willebrand's disease, because its value can be reduced as in cases of hemophilia A.

The platelet count and coagulogram are usually normal.

The vWF antigen dosage is determined by an immunological assay and presents good responses in types 1 and 3, but not in type 2 because type 2 does not always present low concentrations of vWF.

\section{CASE REPORT}

A female patient, 34 years old, white, $49 \mathrm{~kg}$, who underwent 2 Cesarean sections and subsequently a miniabdominoplasty, without complications, complained of hypomastia. The clinical, cardiac, and gynecological examinations and the pre-anesthetic evaluation were normal, as well as the preoperative laboratory tests (blood count, coagulogram, glycemia and urea and creatinine tests).
The first surgical procedure was the inclusion of silicone breast implants under local anesthesia, with intercostal nerve block and sedation performed by the anesthesiologist. The prostheses containing $240 \mathrm{cc}$ of silicone were inserted through the areolas, and the surgery was completed without complications. Vacuum drainage was performed.

The patient recovered without any complications, and the drain was removed on the second day after the surgery, with an output of a small amount of serosanguineous fluid.

On the fourth day after the surgery, an extensive hematoma was identified in the left breast (Figure 1A), and a second surgical procedure was performed under general anesthesia to drain the hematoma. The patient presented diffuse bleeding and, subsequently, a rigorous hemostasis, reintroduction of the left prosthesis, and drainage by vacuum aspiration were performed.

Hematologist assessment was requested and laboratory exams were performed, including a complete blood coagulation study. On the third post-operative day of the hematoma drainage, the drainage output of serosanguineous fluid was only $20 \mathrm{~mL}$ in 24 hours; therefore, the drain was removed and the patient was discharged.

On the thirteenth day after the first surgery and 9 days after the second surgery, the patient presented with bilateral breast hematomas (Figure 1B); the hematoma on the right side was extensive, while that on the left side was moderate.

A third surgery was then performed, and the hematomas of both breasts were drained under general anesthesia. At the time, rigorous hemostasis, reintroduction of both prostheses, and vacuum drainage were performed.

The patient was discharged 3 days after the third surgical procedure, and the drains were maintained until the tenth day, when the volume of the drained fluid was close to $5 \mathrm{~mL}$. The patient recovered well without complications (Figure 2).

At the time of discharge, all the patient's laboratory tests were normal, with the following exceptions: ristocetin cofactor activity: 23\% (N: $56-187 \%$ ), and vWF antigen: $20 \%$ (N: 50-150\%).
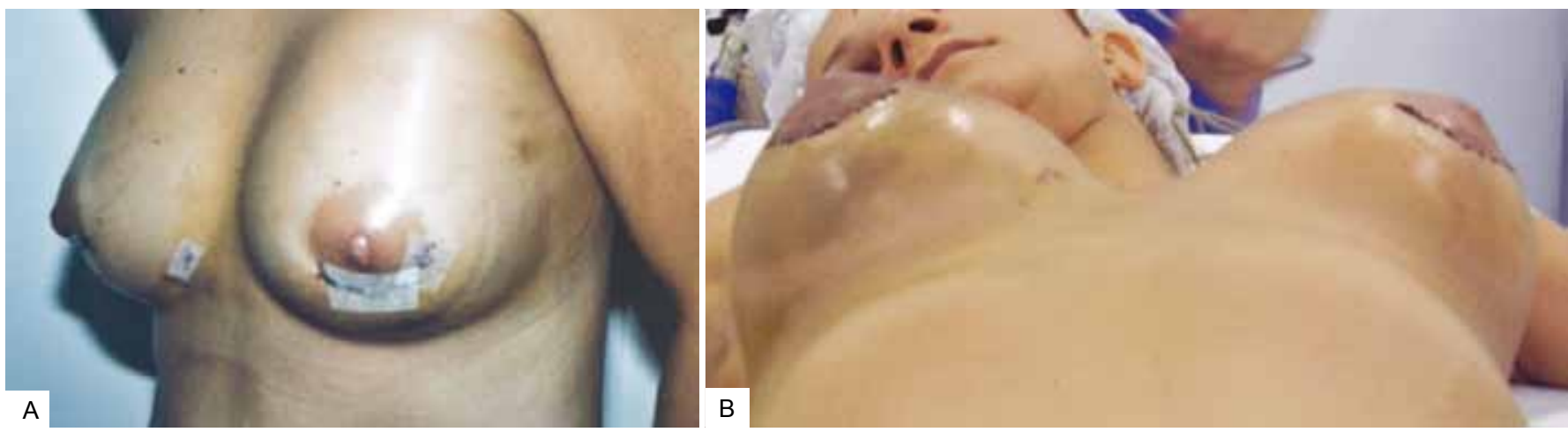

Figure 1-A: Hematoma in the left breast. B: Bilateral hematoma on the thirteenth postoperative day of augmentation mammaplasty. 

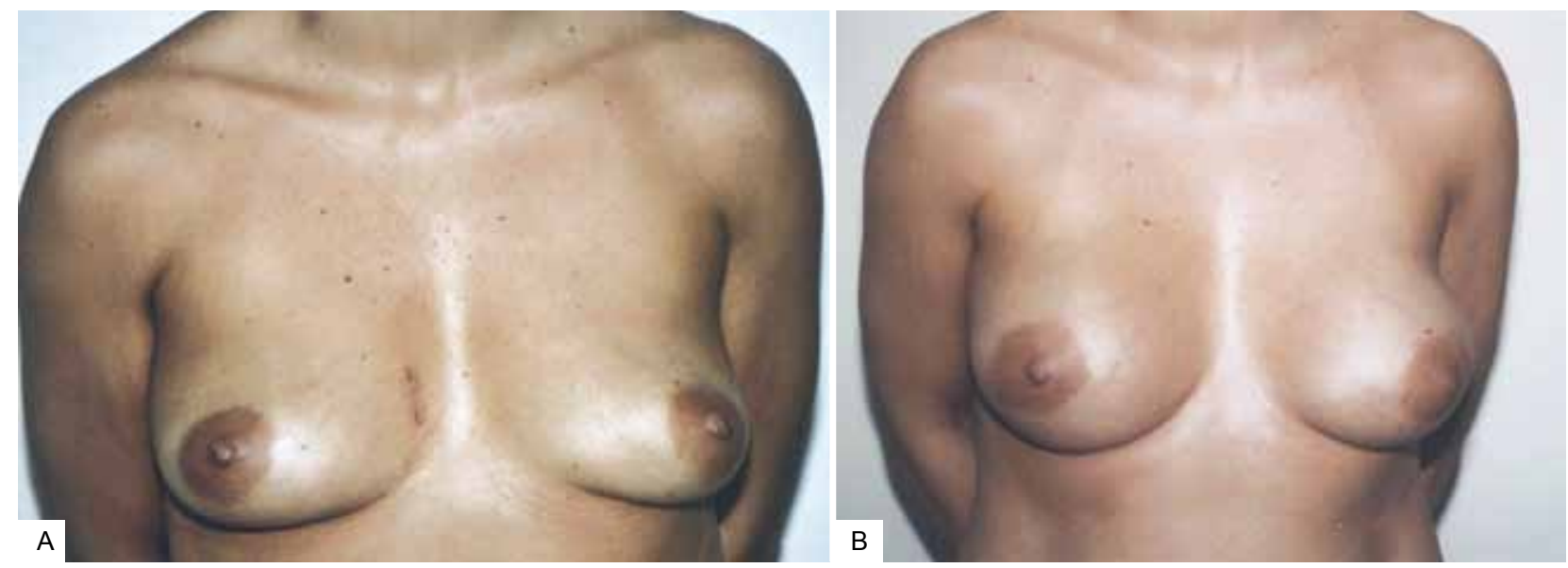

Figure 2 - A: Preoperative augmentation mammaplasty. B: Six months after augmentation mammaplasty surgery.

After the third surgical procedure, von Willebrand's disease type 1 was diagnosed.

After discharge and at the behest of the hematologist, laboratory tests were performed on the patient's daughter, and she was found to have the same type of von Willebrand's disease ${ }^{1}$.

\section{DISCUSSION}

In our case study, von Willebrand's disease had not been diagnosed prior to surgery because of the following factors:

- The patient did not report clotting disorders;

- There was no recorded family history of coagulopathy because the patient had been adopted;

- The patient did not use medication that could have interfered with coagulation;

- The patient had 2 previous Cesarean sections without any bleeding complications;

- There was no report of bleeding problems during intraoperative and postoperative periods when infraumbilical mini-abdominoplasty was performed 4 years earlier by the same surgeon;

- Laboratory tests, including the coagulogram, were normal.

Several cases of von Willebrand's disease diagnosed during surgery have been described in the literature, which facilitated the establishment of the correct therapeutic procedure ${ }^{4-6}$.

Our case was unusual because the diagnosis was made after the surgery was performed, which delayed and complicated the treatment.

There was no bleeding during the 2 Caesarean procedures because factor VIII increases during pregnancy to protect the patient.
The mini-abdominoplasty, performed 4 years earlier, was not only a more minor surgical procedure, but was followed by rigorous hemostasis, internal fixation suture points ${ }^{7}$, vacuum drainage and compression with elastic stockings were achieved to prevent a possible bleeding.

During augmentation mammaplasty, in spite of rigorous hemostasis, bleeding occurred 4 days after the initial operation and 13 days after the second surgical procedure. The friction between the textured surface of the prostheses (rough) and the bloody surface of a patient with a predisposition to bleeding (patients with undiagnosed von Willebrand's disease type 1) may facilitate the formation of hematomas after surgery.

We believe that very rigorous hemostasis and the maintenance of drains for a period of 10 days were important factors in preventing another hematoma after the third surgical procedure.

Because specific tests for von Willebrand's disease are not part of the routine preoperative examinations before plastic surgery, it is important to investigate the clinical and family history of bleeding disorders.

In the case of suspected von Willebrand's disease, the APTT and factor VIII, ristocetin cofactor, and von Willebrand factor antigen levels should be determined. In addition, the patient should be examined by a hematologist to avoid possible complications. Apart from the APTT, the other tests are not routine preoperative tests because they are performed in major centers and the results are protracted.

\section{REFERENCES}

1. Kessler CM. Deficiências dos fatores de coagulação. In: Goldman L, Bennet JC, eds. Tratado de medicina interna. 21 $1^{\mathrm{a}}$ ed. Rio de Janeiro: Guanabara Koogan; 2001. p. 1121-3.

2. Nitu-Walley IC, Griffioen A, Harrington C, Lee CA. Retrospective review of the management of elective surgery with desmopressin and 
clotting factor concentrates in patients with von Willebrand disease. Am J Hematol. 2001;66(4):280-4.

3. von Willebrand EA. Hereditär pseudohemofili. Finska Läkaresällskapets Handlingar. 1926;67:87-112.

4. Saroute ANR, Brandão CMA, Guedes MAV, Cavalheiro Filho C, Pomerantzeff PMA. Paciente portadora de doença de von Willebrand submetida a cirurgia da valva mitral: uma estratégia para o controle da coagulopatia. Arq Bras Cardiol. 2007;88(1):e4-e6.
5. Matos Júnior RM, Godoy RC, Gobbo MC, Lian Júnior J, Duz GL. Rinoplastia em paciente com doença de von Willebrand: relato de caso. Rev Bras Anestesiol. 2007;57(6):678-83.

6. Marques MPC, Leite EST. Cuidados nos pacientes com hemofilia e doença de von Willebrand na cirurgia eletiva otorrinolaringológica. Rev Bras Otorrinolaringol. 2003;69(1):40-6.

7. Baroudi R, Ferreira CA. Seroma: how to avoid it and how to treat it. Aesthet Surg J. 1988;18(6):439-41.

\section{Correspondence to:}

Marco Willians Baena Destro

Rua Joaquim Tavares, 50 - Centro - Taubaté, SP, Brazil - CEP 12020-280

E-mail:marcodestro@uol.com.br 